\title{
RANCANG BANGUN INFORMASI WISATA BATURADEN MENGGUNAKAN WEBBASE DI KABUPATEN BANYUMAS
}

\author{
Rahayu Noveandini ${ }^{1}$, Maria Sri Wulandari ${ }^{2}$ \\ 1) Prodi Sistem Informasi, Sekolah Tinggi Manajemen Informatika dan Komputer Jakarta STI\&K \\ ayu.noveandini@gmail.com \\ 2) Prodi Sistem Informasi, Sekolah Tinggi Manajemen Informatika dan Komputer Jakarta STI\&K \\ mswuland@yahoo.com
}

\begin{abstract}
Abstrak
Kabupaten Banyumas merupakan salah satu kabupaten di provinsi Jawa Tengah. Kabupaten Banyumas memiliki sebuah tempat wisata yang merupakan salah satu tempat wisata unggulan yang banyak diminati oleh masyarakat Kabupaten Banyumas sendiri maupun masyarakat dari daerah sekitarnya, yaitu Wisata Alam Baturaden. Kawasan Wisata Alam Baturaden merupakan salah satu daerah tujuan wisata yang cukup potensial. Dari sebelas obyek wisata yang ada di Kabupaten Banyumas sebanyak lima obyek wisata berada di Kawasan Wisata Baturaden.

Permasalahan yang terjadi adalah belum adanya aplikasi yang menjelaskan informasi wisata alam Baturaden yang dapat diakses secara online sehingga banyak wisatawan daerah lain yang belum mengenal wisata alam ini. Disamping itu belum adanya sarana untuk menjelaskan fasilitas - fasilitas yang berada dekat dengan wisata alam ini. Melihat dari permasalahan yang terjadi dan untuk membantu memperkenalkan Wisata Alam Baturaden, dengan ini akan dibuat sebuah website menggunakan PHP sebagai web desain. Metode penelitian ini menggunakan metode SDLC (System Development Life Cycle) dengan tujuan untuk memperkenalkan obyek wisata alam di Baturaden dan rancangannya menggunakan UML (Unified Modelling Language).
\end{abstract}

Kata Kunci : Rancang Bangun, Wisata Alam, Baturaden, Kabupaten Banyumas, UML Diagram

\section{Pendahuluan}

Kabupaten Banyumas merupakan salah satu kabupaten di provinsi Jawa Tengah. Kabupaten ini berbatasan dengan Kabupaten Brebes di utara, Kabupaten Purbalingga, Kabupaten Banjarnegara, Kabupaten Kebumen, serta Kabupaten Cilacap di sebelah selatan dan barat. Gunung Slamet, gunung tertinggi di Jawa Tengah terdapat di ujung utara wilayah kabupaten ini.

Sebagai negara yang berada di daerah tropis, Indonesia memiliki banyak potensi wisata berupa keindahan alam sebagai daya tarik wisata. Ada banyak daerah termasuk Jawa Tengah yang memiliki obyek wisata alam dengan keindahan alam sebagai daya tarik utamanya, misalnya Tawangmangu, Bandungan, Baturaden, dan lain-lain. Ada beberapa alasan mengapa keindahan alam menarik bagi wisatawan, diantaranya : wisatawan tertarik oleh kegiatan-kegiatan yang dilakukan di alam terbuka, orang sering mengadakan perjalanan akhir pekan ke daerah dengan suasana pedesaan atau kehidupan di luar kota, banyak wisatawan yang mencari ketenangan di tengah alam yang iklimnya nyaman, pemandangannya bagus dan terbuka luas, dan alam juga sering menjadi bahan studi untuk wisata.

Kawasan Wisata Baturaden yang berada di Kabupaten Basnyumas merupakan salah satu daerah tujuan wisata yang cukup potensial. Dari sebelas obyek wisata yang ada di Kabupaten Banyumas sebanyak lima obyek wisata berada di Kawasan Wisata Baturaden. Kawasan Wisata Baturaden menjadi kawasan wisata unggulan Kabupaten Banyumas yang banyak 
dikunjungi oleh masyarakat Kabupaten Banyumas sendiri maupun masyarakat di kabupaten-kabupaten sekitarnya. Baturaden telah dikenal sebagai Kawasan wisata dengan berbagai obyek wisata yang ada dan fasilitas pendukungnya yang cukup lengkap. Selain wisatawan regional, wisatawan mancanegara juga banyak yang berkunjung ke Baturaden, sehingga skala pelayanan selain regional juga internasional.

Permasalahan yang terjadi adalah belum adanya aplikasi yang menjelaskan informasi wisata alam Baturaden secara online sehingga banyak wisatawan yang belum mengetahui mengenai wisata alam ini. Disamping itu belum adanya sarana untuk menjelaskan fasilitas - fasilitas yang dekat dengan wisata alam ini. Melihat dari permasalahan yang terjadi dan untuk membantu memperkenalkan Wisata Alam Baturaden, dengan ini akan dibuat sebuah webbase menggunakan PHP. Website ini memuat tentang Wisata Alam Baturaden, dimana tempatnya mempunyai keindahan alam yang sangat menarik, juga merupakan salah satu tempat wisata yang banyak memiliki nilai edukasi, namun banyak beberapa turis lokal maupun mancanegara yang belum mengetahui tentang objek wisata alam yang terdapat di Baturaden.

\section{Struktur Navigasi}

Strukur navigasi adalah urutan alur informasi dari suatu aplikasi multimedia, dengan menggunakan struktur navigasi yang tepat maka suatu aplikasi multimedia mempunyai suatu pedoman dan arah informasi yang jelas. Ada 4 macam struktur navigasi yang digunakan, yaitu struktur navigasi linier, struktur navigasi non linier, struktur navigasi hirarki dan struktur navigasi campuran.

\section{UML (Unified Modelling Language)}

Unified Modelling Language (UML) adalah sebuah "bahasa" dan "aturan" yang spesifikasi menjadi standar dalam industri untuk memvisualisasikan, menspesifikasikan, membangun dan pendokumentasian dari sebuah sistem pengembangan perangkat lunak berbasis objek. Diagram UML yang digunakan pada penelitian ini adalah :

Use Case Diagram

Diagram Use Case yaitu salah satu jenis bagan pada UML yang menggambarkan interaksi antara sistem dan aktor, Use Case Diagram juga dapat mendeskripsikan tipe interaksi antara si pemakai sistem dengan sistemnya.

Sequence Diagram

Sequence Diagram yaitu salah satu jenis diagram pada UML yang menjelaskan interaksi objek yang berdasarkan urutan waktu, sequence diagram juga dapat menggambarkan urutan atau tahapan yang harus dilakukan untuk dapat menghasilkan sesuatu seperti pada Use Case Diagram.

\begin{tabular}{|l|l|l|}
\hline No & \multicolumn{1}{|c|}{ Tahapan } & \multicolumn{1}{c|}{ Keterangan } \\
\hline 1 & Identifikasi Masalah & $\begin{array}{l}\text { Kurangnya informasi pada masyarakat luas mengenai wisata alam } \\
\text { khususnya wisata alam Baturaden. }\end{array}$ \\
\hline 2. & Analisis Kebutuhan Sistem & $\begin{array}{l}\text { Pada tahap ini melakukan analisis kebutuhan sistem yang } \\
\text { digunakan untuk membangun aplikasi wisata tersebut baik dari } \\
\text { hardware (perangkat keras) maupun dari software (perangkat } \\
\text { lunak). }\end{array}$ \\
\hline 3. & Perancangan Sistem & $\begin{array}{l}\text { Perancangan sistem ini menggunakan UML Diagram yaitu : } \\
\text { Use Case Diagram } \\
\text { Diagram Activity } \\
\text { Sequence Diagram }\end{array}$ \\
\hline 4. & Uji coba dan Implementasi & $\begin{array}{l}\text { Pada tahap ini dilakukan uji coba aplikasi yang sudah terbentuk } \\
\text { dan dilakukan implementasi dari aplikasi tersebut. }\end{array}$ \\
\hline
\end{tabular}


Activity Diagram

bentuk visual dari alur kerja yang berisi aktivitas dan tindakan, yang juga dapat berisi pilihan, atau pengulangan. Dalam Unified Modeling Language(UML), diagram aktivitas dibuat untuk menjelaskan aktivitas komputer maupun alur aktivitas dalam organisasi. Selain itu diagram aktivitas juga menggambarkan alur kontrol secara garis besar.

\section{Metode Penelitian}

Pada metode penelitian ini menggunakan SDLC (System Development Life Cycle). Tahapan penelitian dengan SDLC pada aplikasi informasi wisata alam Baturaden ini adalah seperti terlihat pada tabel 1 dan gambar SDLC terlihat pada gambar 1. Tabel 1. Tahapan Metode Penelitian

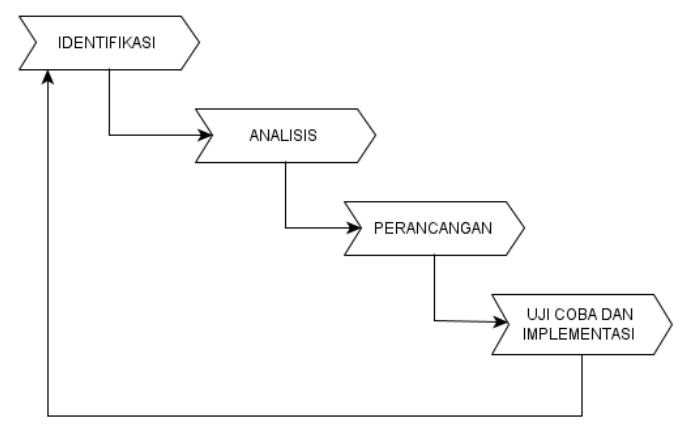

Gambar 1. Bagan SDLC

\section{Hasil dan Pembahasan}

Website wisata alam Baturaden ini termasuk ke dalam golongan website yang memiliki struktur navigasi composite, merupakan suatu struktur navigasi bebas karena struktur ini dapat memberikan keinteraksian yang lebih tinggi terhadap website. Struktut navigasi pada penelitian adalah seperti terlihat pada gambar 2 .

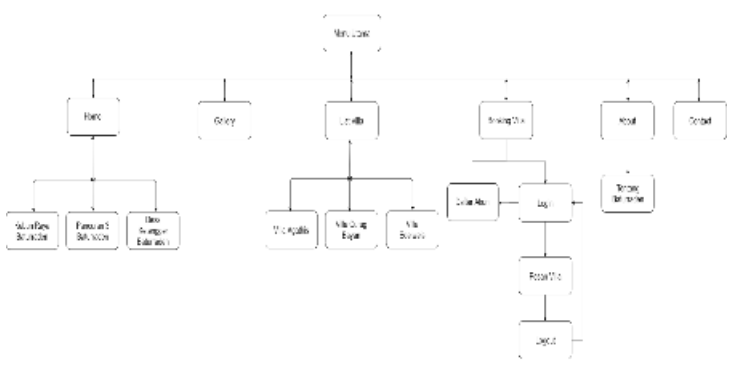

Gambar 2. Struktur Navigasi Aplikasi Wisata Baturaden

Perancangan Unified Modeling Language

Model yang digunakan untuk merancang aplikasi berbasis website ini adalah unified modeling language (UML). UML digunakan untuk mempermudah dalam memahami rancangan sebuah sistem, alat bantu yang digunakan yaitu :

1. Use Case Diagram

Use Case Diagram menggambarkan fungsi yang diharapkan dari sebuah aplikasi. Use Case Diagram merepresentasikan interaksi antara aktor dengan aplikasi.

2. Sequence Diagram

Sequence digunakan untuk
menggambarkan skenario atau
rangkaian langkah-langkah yang
dilakukan sebagi respon dari sebuah
event untuk menghasilkan output
tertentu.

3. Activity Diagram

Activity Diagram adalah sebuah diagram alur kerja yang menjelaskan berbagai kegiatan pengguna atau sistem, orang yang melakukan masing - masing aktivitas dan aliran sequensial dari aktivitas tersebut.

\section{Use Case Diagram}

Pada website aplikasi pengenalan wisata alam Baturaden ini menggunakan satu aktor yang berperan yaitu user seperti terlihat pada gambar 3 . 


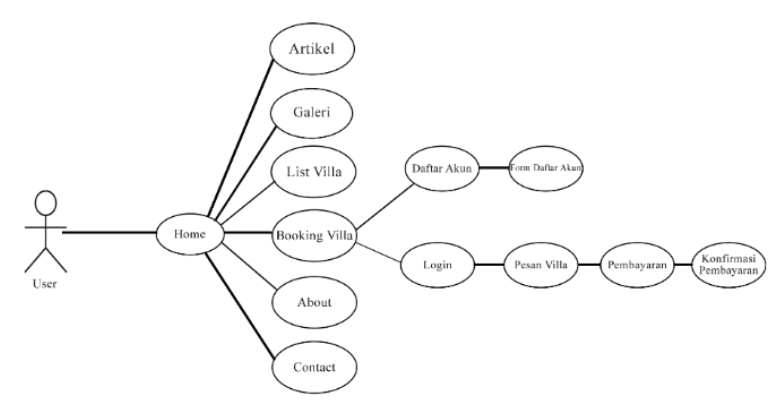

Gambar 3. Use Case Diagram Wisata Alam Baturaden

\section{Sequence Diagram}

Sequence Diagram digunakan untuk menggambarkan secara khusus perilaku sebuah scenario tunggal. Sequence Diagram menunjukan interaksi dengan menampilkan partisipan dengan garis alur secara vertikal dan pengurutan pesan dari atas ke bawah. Sequence Diagram pada website aplikasi pengenalan wisata alam Baturaden menggunakan User Sequence Diagram yang dapat dilihat pada gambar 4.

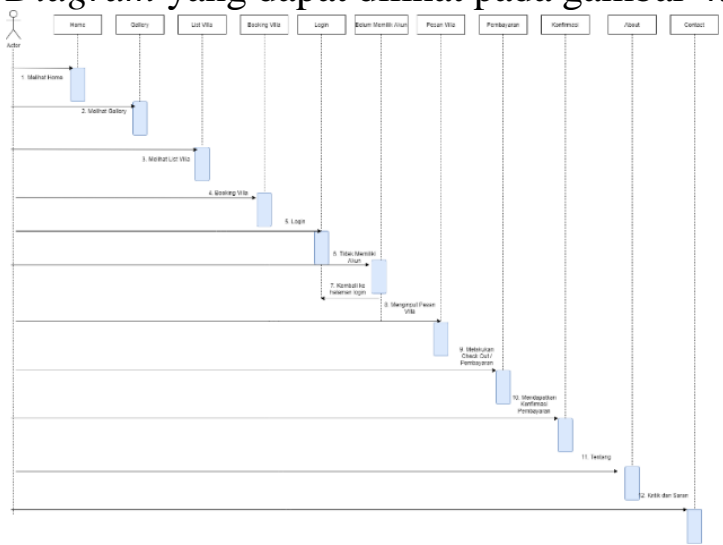

Gambar 4. User Sequence Diagram

\section{Activity Diagram}

Activity Diagram adalah sebuah diagram alur kerja yang menjelaskan berbagai kegiatan pengguna atau sistem, orang yang melakukan masing - masing aktivitas dan aliran sequential dari aktivitas tersebut. Activity diagram disini menjelaskan skenario yang dilakukan oleh user untuk melakukan pemesanan villa. Dapat dilihat pada gambar 5.

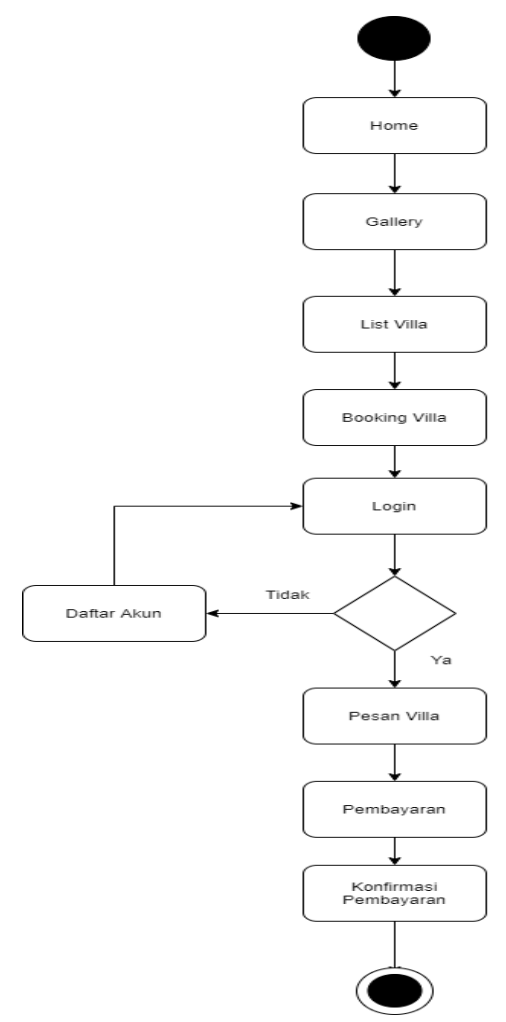

Gambar 5. Activity Diagram Wisata Alam Baturaden

\section{Rancangan Website}

Langkah pertama yang dilakukan dalam pembuatan website adalah merancang secara manual. Setelah dibuat sebuah rancangan secara manual untuk menentukan halaman-halaman web yang dibutuhkan dalam elemen-elemen pendukungnya, seperti mengumpulkan bahan-bahan yang akan ditampilkan dalam website, yaitu gambar-gambar dan informasi tentang wisata alam Baturaden.

\section{Rancangan Halaman Home}

Halaman Home adalah halaman utama website yang akan dilihat pengunjung untuk pertama kali. Dihalaman ini pengunjung dapat melihat sekilas tentang website wisata alam Baturaden seperti pada gambar 6. 


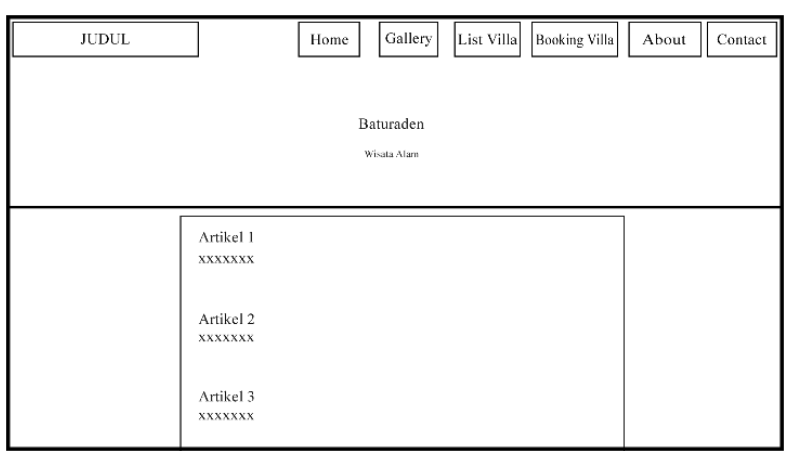

Gambar 6. Rancangan Halaman Home

Pada tampilan rancangan halaman home judul 1 merupakan judul dari Wisata Alam Baturaden.

Sedangkan tampilan halaman home terlihat pada gambar 7 .

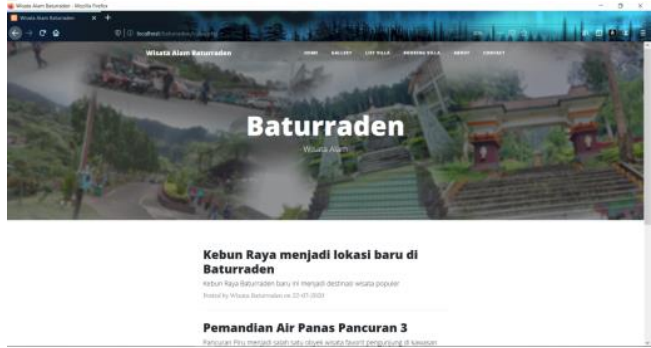

Gambar 7. Tampilan Halaman Home

\section{Rancangan Halaman Gallery}

Pada halaman ini berisikan kumpulan gambar-gambar dari pemandangan objek wisata daerah Baturaden seperti pada gambar 8 .

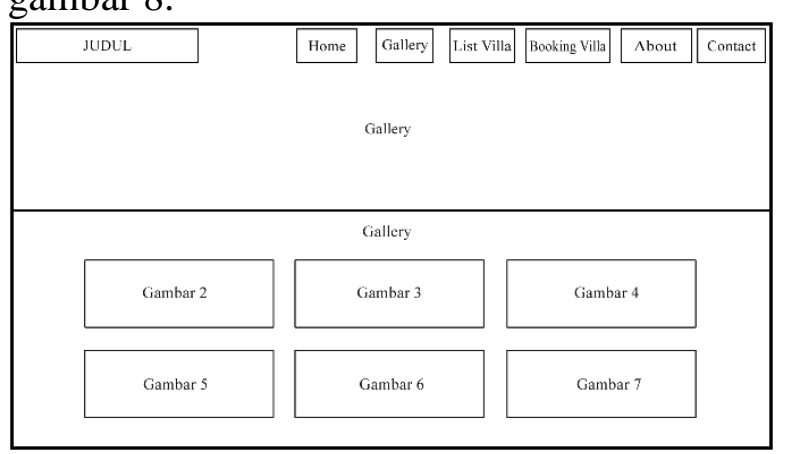

Gambar 8. Rancangan Halaman Gallery Pada tampilan rancangan Halaman Gallery gambar 2 merupakan gambar pintu masuk Wisata Alam Baturaden. Gambar 3 adalah gambar pemandangan di dalam objek Wisata Alam Baturaden, dan gambar 4 merupakan gambar daerah parkir Wisata Alam Baturaden. Gambar 5 adalah gambar pemandangan objek Wisata Alam
Baturaden. Gambar 6 merupakan gambar air terjun Wisata Alam Baturaden. Gambar 7 adalah gambar area pedagang sekitaran wilayah Wisata Alam Baturaden. Tampilan Halaman Gallery terlihat pada gambar 9.

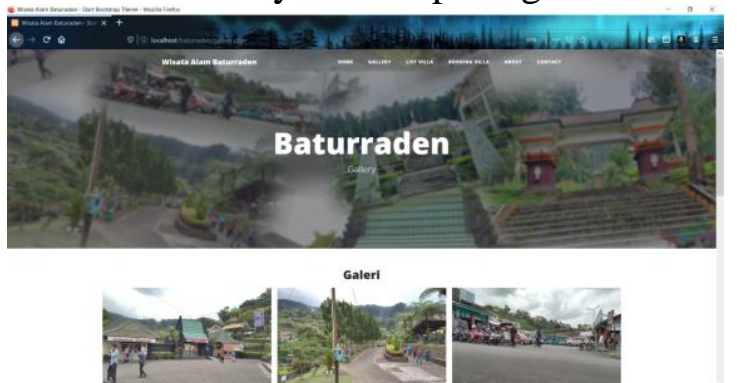

Gambar 9. Tampilan Halaman Gallery

Rancangan Halaman List Villa

Pada halaman ini berisikan tentang informasi list villa atau penginapan yang ada di sekitar daerah Baturaden. Pengunjung dapat mengklik judul list villa, maka akan muncul tentang informasi villa seperti pada gambar 10 .

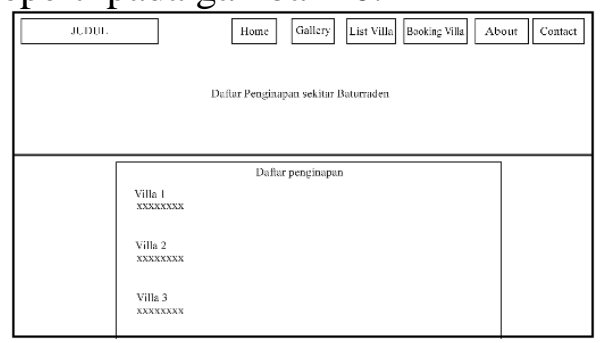

Gambar 10. Rancangan Halaman List Villa Tampilan Halaman List Villa terlihat pada gambar 11.

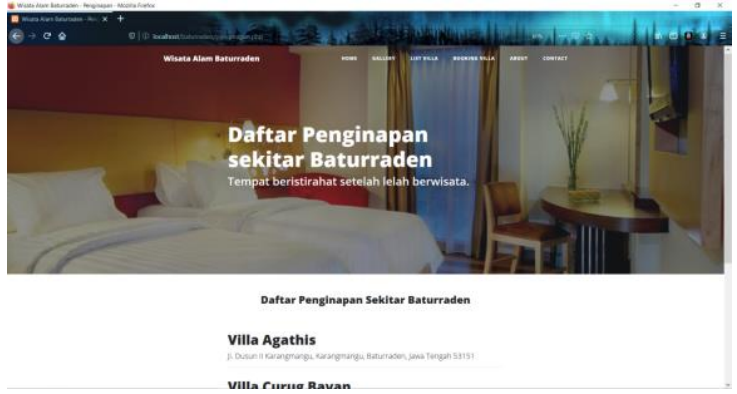

Gambar 11. Halaman List Villa

\section{Rancangan Halaman Login}

Pada halaman ini berisikan tentang bagian untuk login pengguna sebelum melakukan pemesanan villa seperti pada gambar 12. 


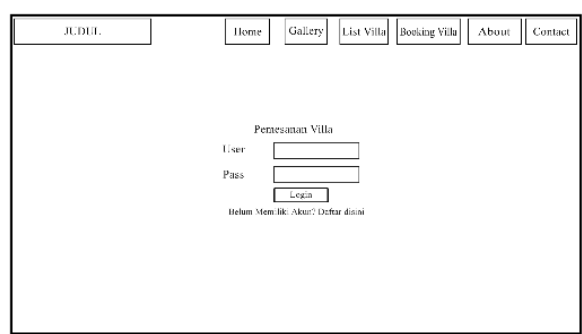

Gambar 12. Rancangan Halaman Login Tampilan Halaman Login terlihat pada gambar 13.

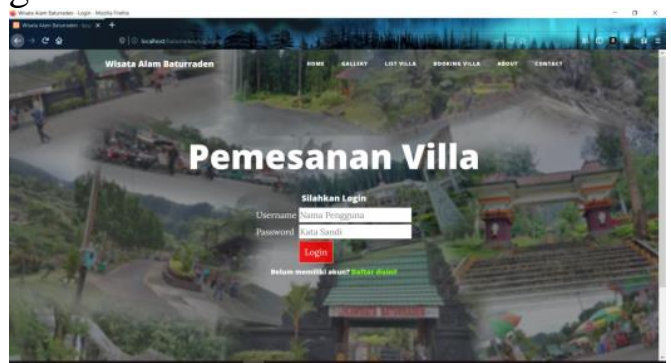

Gambar 13. Tampilan Halaman Login

\section{Rancangan Halaman Pemesanan Villa}

Pada halaman ini berisikan tentang pemesanan villa atau penginapan disekitar Wisata Alam Baturaden seperti pada gambar 14.

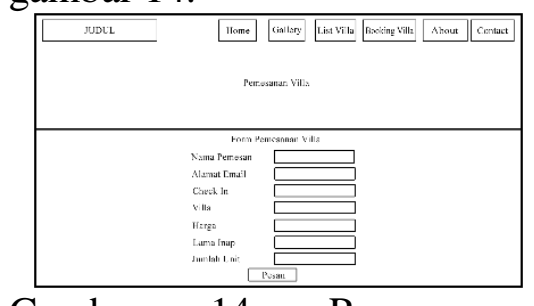

Gambar 14. Rancangan Halaman Pemesanan Villa

Tampilan Halaman Pemesanan Villa terlihat pada gambar 15 .
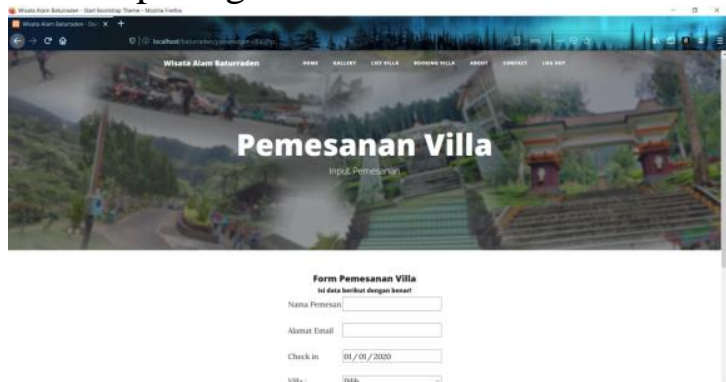

Gambar 15. Tampilan Halaman Pemesanan Villa

\section{Rancangan Halaman Pembayaran Villa} Pada halaman ini berisikan tentang pembayaran dari pemesanan villa disekitar Wisata Alam Baturaden seperti pada gambar 16.

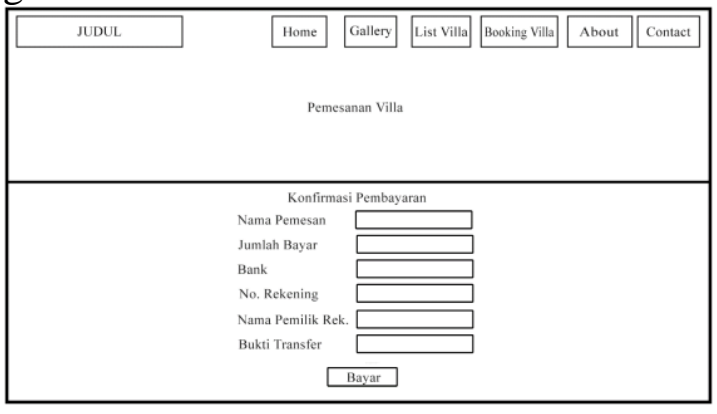

Gambar 16. Rancangan Halaman Pembayaran Villa

Tampilan Halaman Pembayaran Villa terlihat pada gambar 17.

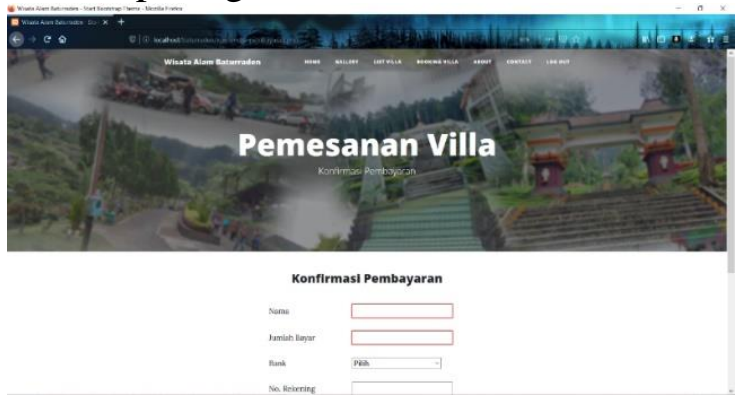

Gambar 17. Tampilan Halaman

Pembayaran Villa

\section{Rancangan Halaman About}

Pada halaman ini berisikan tentang deksripsi, letak geografis, dan jarak untuk menuju Wisata Alam Baturaden. Pengunjung dapat mengklik gambar, maka akan terlihat penjelasan arah menuju Wisata Alam Baturaden seperti pada gambar 18.

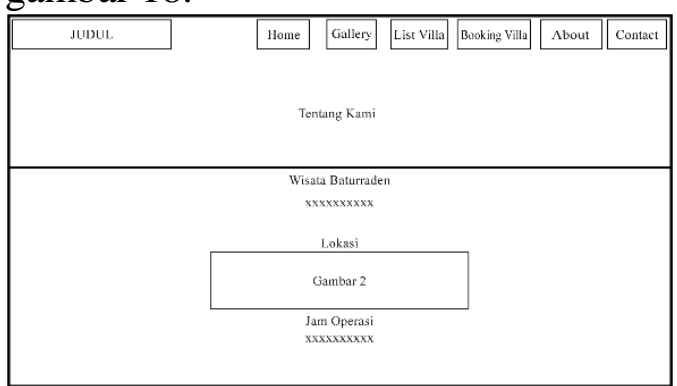

Gambar 18. Rancangan Halaman About 
Tampilan Halaman About seperti terlihat pada gambar 19.

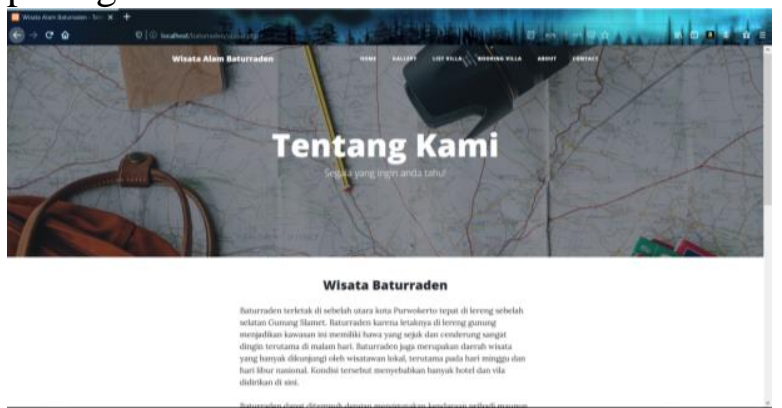

Gambar 19. Tampilan Halaman About

\section{Rancangan Halaman Contact}

Pada halaman ini berisikan tentang form kritik dan saran. Pengguna bisa menulis kritik dan saran dengan mengisi form tersebut. Kritik dan saran tersebut akan di kirim langsung ke email pembuat website tersebut seperti pada gambar 20 .

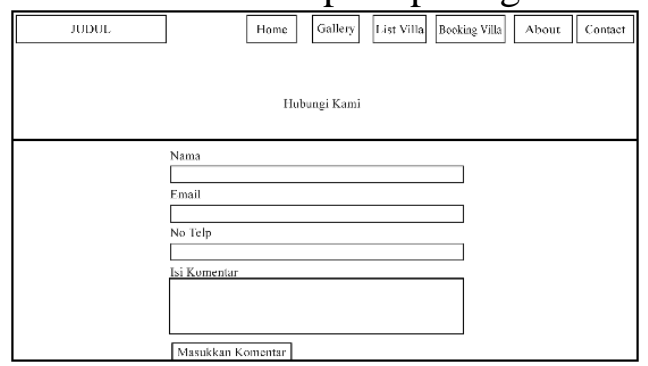

Gambar 20. Rancangan Halaman Contact Tampilan Halaman Contact terlihat pada gambar 21.

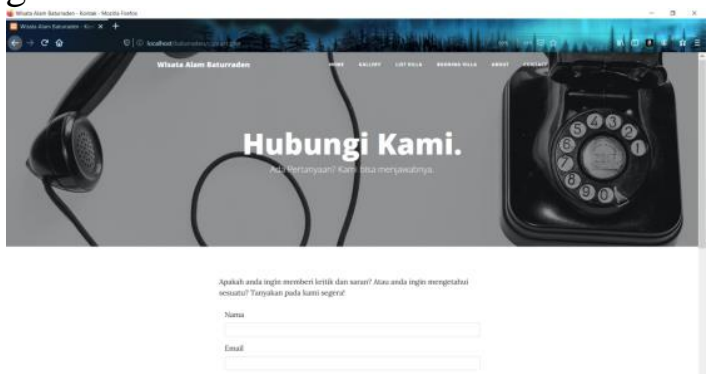

Gambar 21. Halaman Contact

Uji Coba Aplikasi

Pengujian aplikasi berbasis kinerja browser pada website merupakan percobaan yang menggunakan website browser tertentu. Tabel 2 menunjukkan pengujian kinerja browser yang digunakan. Tabel 2. Rangkuman Hasil Pengujian Kinerja Browser

\begin{tabular}{|c|c|c|}
\hline \multirow[t]{2}{*}{ Metode } & $\begin{array}{l}\text { Web browser } \\
\text { yang }\end{array}$ & \multirow[t]{2}{*}{ Hasil } \\
\hline & $\begin{array}{c}\text { Ruang } \\
\text { lingkup }\end{array}$ & \\
\hline \multirow[t]{12}{*}{ Browser } & \multicolumn{2}{|l|}{ Google chrome } \\
\hline & Tampilan & $\begin{array}{l}\text { Tampilan } \\
\text { halaman web } \\
\text { terlihat fleksibel } \\
\text { dan sesuai } \\
\text { ukuran. }\end{array}$ \\
\hline & Kecepatan & $\begin{array}{l}\text { Cepat dalam } \\
\text { dalam } \\
\text { membuka } \\
\text { halaman }\end{array}$ \\
\hline & Stabilitas & $\begin{array}{l}\text { Baik tidak ada } \\
\text { error }\end{array}$ \\
\hline & \multicolumn{2}{|l|}{ Mozila firefox } \\
\hline & Tampilan & $\begin{array}{l}\text { Tampilan } \\
\text { halaman web } \\
\text { terlihat fleksibel } \\
\text { dan sesuai } \\
\text { ukuran. } \\
\end{array}$ \\
\hline & Kecepatan & $\begin{array}{l}\text { Cepat dalam } \\
\text { dalam } \\
\text { membuka } \\
\text { halaman }\end{array}$ \\
\hline & Stabilitas & $\begin{array}{l}\text { Baik tidak ada } \\
\text { error }\end{array}$ \\
\hline & \multicolumn{2}{|c|}{ Opera Browser } \\
\hline & Tampilan & $\begin{array}{lr}\text { Tampilan } & \text { web } \\
\text { kurang fleksibel } \\
\text { dan } & \text { terlihat } \\
\text { sedikit } & \text { lebih } \\
\text { besar. } & \\
\end{array}$ \\
\hline & Kecepatan & $\begin{array}{l}\text { Sedikit lama } \\
\text { dalam memuat } \\
\text { halaman web }\end{array}$ \\
\hline & Stabilitas & $\begin{array}{l}\text { Baik tidak ada } \\
\text { error }\end{array}$ \\
\hline
\end{tabular}

\section{Penutup}

Kesimpulan dari penelitian ini adalah dengan adanya aplikasi website pengenalan wisata alam Baturaden ini dapat memudahkan para wisatawan baik wisatawan domestik maupun mancanegara untuk dapat mengetahui informasi tentang wisata alam Baturraden dan fasilitas apa saja yang ada didaerah sekitar wisata.

$$
\text { Aplikasi ini dibangun }
$$
menggunakan struktur navigasi campuran 
dan UML Diagram untuk menggambarkan pemodelan visual berbasis perangkat lunak yang terbentuk adalah Use Case diagram, Activity Diagram dan Sequence Diagram.

Berdasarkan hasil uji coba aplikasi website Pengenalan Wisata Alam Baturraden, maka aplikasi ini terbangun dari database dan design form. Telah diuji coba pada tiga web browser yaitu Google Chrome, Mozilla Firefox, Opera Mini dan sangat berjalan dengan baik pada browser Mozilla Firefox dari sisi tampilan halaman web terlihat fleksibel dan sesuai ukuran dan cepat dalam membuka halaman.

\section{DAFTAR PUSTAKA}

[1] Kasi Nisasfil Dinbudpar, Sejarah Kebudayaan Banyumas. Dinbudpar, Banyumas, 2008
[2] Rintho Rante Rerung. Pemrograman Web Dasar. Deepublish Publisher. Yogyakarta: 2016

[3] Muhammad Ibnu Sa'ad, Otodidak Web Programming: Membuat Website Edutainment, PT Elex Media Komputindo, Jakarta, 2020.

[4] Anhar. Panduan Menguasai PHP \& MySQL Secara Otodidak. Mediakita, Jakarta Selatan, 2015.

[5] Kusno Harianto, Sistem Monitoring Lulusan Perguruan Tinggi Dalam Memasuki Dunia Kerja Menggunakan Tracker Study, Media Sahabat Cendekia, Surabaya, 2019.

[6] Ahmad Nurcholish, Membangun database arsip persuratan menggunakan pemrograman PHP dan MySQL, CV Jejak, Jawa Barat, 2018 